$\mathrm{Oz}$

Volume 24

Article 7

$1-1-2002$

\title{
The Landscape of a Building
}

Susan Weiler

Follow this and additional works at: https://newprairiepress.org/oz

(c) (i) $\Theta(9$

This work is licensed under a Creative Commons Attribution-Noncommercial-No Derivative Works 4.0 License.

\section{Recommended Citation}

Weiler, Susan (2002) "The Landscape of a Building," Oz: Vol. 24. https://doi.org/10.4148/2378-5853.1373

This Article is brought to you for free and open access by New Prairie Press. It has been accepted for inclusion in Oz by an authorized administrator of New Prairie Press. For more information, please contact cads@k-state.edu. 


\section{The Landscape of a Building}

\section{Susan Weiler}

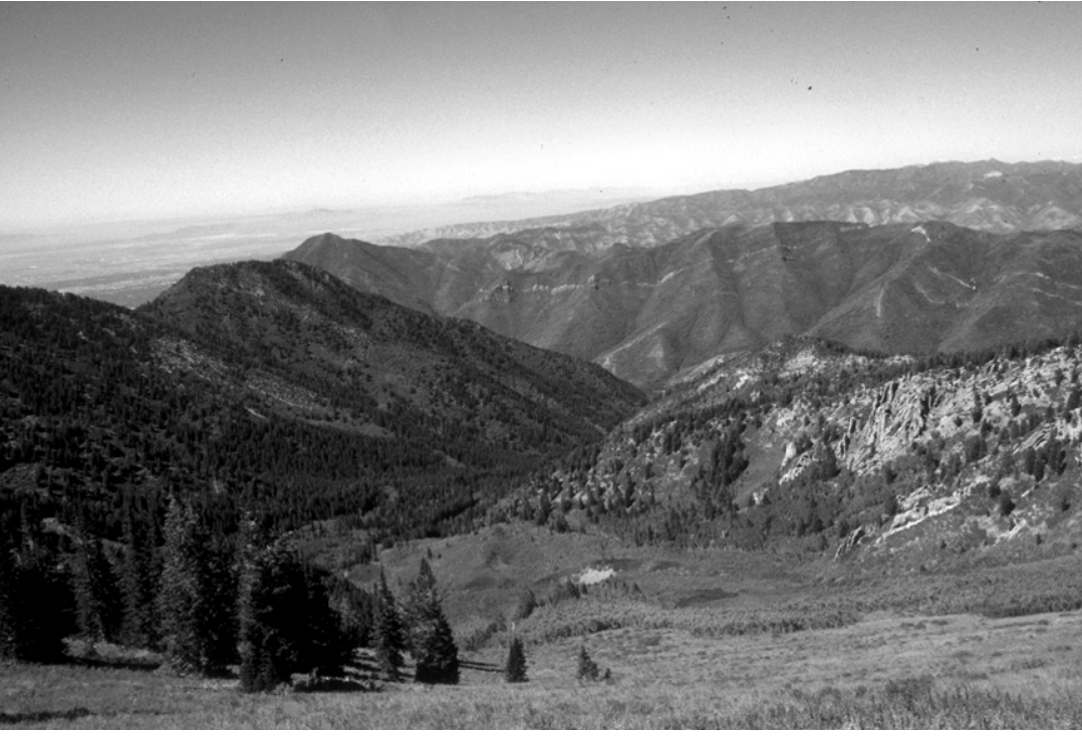

Wasatch Mountains.
While cities might seem to be spontaneously constructed living things, they rarely are random assemblages of buildings, streets, open spaces, and people. Nor do they operate through an ambiguous set of natural and artificial processes. Rather, they are a complex integration of layers of physical and social fabric shaped by natural, cultural, and economic resources and influences. Cities do, however, represent the physical and social intentions, as well as the achievements and failures, of their founders, creators, and inhabit ants, and do, indeed, become part of the larger landscape.

Few cities, upon the initial deciphering of their layers, appear to be more intentional and less ambiguous in their collective form than Salt Lake City, Utah. Sprawling across a desert valley, contained by mountains and shaped by the enduring influence of the Church of the Latter-day Saints, the city clearly has become part of the greater landscape.

It is difficult to find a building that has been more intentional and less ambiguous in integrating its form and function with both the immediate landscape of the city and the greater landscape than the Conference Center of the Church of the Latter-day Saints. Expressing many of the integrated layers of Salt Lake City-natural, physical, and cultural-the Conference Center has become a microcosm of the city
The physical and cultural form of Salt Lake City, in which the Conference Center sits and to which it must respond, stems directly from the actions of its pioneer founders of the mid-nineteenth century.

Leading a religiously persecuted people from their besieged settlement in Illinois, Brigham Young-successor to Joseph Smith, founder of the Church of the Latter-day Saints-brought his pioneers through the Great Plains and across the mountains, stopping only when he reached the Great Salt Lake Valley. In this desert valley surrounded by the Wasatch Mountains on the east and the Oquirrh Range to the west, Young ended the journey, determining, "this is the place."

In a matter of days, Young began to lay out an agrarian village based on the ideal City of Zion that Joseph Smith had planned. Its large, ten acre blocks were divided by straight, wide streets set out on compass north and prefixed "north," "south," "east," and "west" from a center point-the Temple. From Salt Lake City, Mormonism spread throughout Utah, with more than 350 communities established using the same city plan.

Left to grow in this isolation, Mormonism flourished as the West expanded. The completion of the transcontinental railroad in 1869 led to greater ethnic, religious, and economic diversity and the eventual urbanization of Salt Lake. 


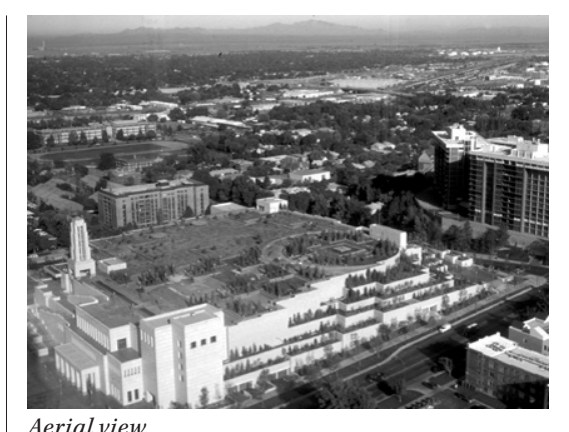

Aerial view.

Still, the city remained influenced by its Mormon founders.

Today Salt Lake is a major urban force and the political, cultural, educational, and financial center of the state and region. But even in its current urban form, observers can trace the original, idealized plan. What is also discernable is Salt Lake's struggle to reconcile its century and a half of growth with the natural landscape and forces of a desert valley surrounded by mountains.

Its enormously wide streets and ten acre blocks impart an air of gigantism and expansiveness. These large, long blocks are filled unevenly with differing styles and heights of buildings amidst the even larger vastness of the valley and mountains, leaving the resulting impression of a city poorly integrated into the larger landscape.

The Central Business District has evolved on the blocks south of Temple Square. To the north of the square, the toe of the slope of Capitol Hill begins its rise to the foothills and mountains beyond. The rail yards and depots of the Rio Grand and Union Pacific spread like industrial relics to the west.

Temple Square is at the center of the city and consists of the Temple, Tabernacle, Visitor Centers, libraries, and a number of administrative buildings, loosely knit together by fountains and small gardens. As intended by the founders, it remains the spiritual and

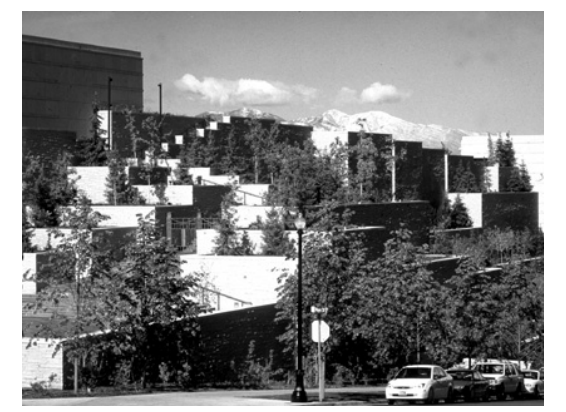

View from northeast.

administrative heart of the Church of the Latter-day Saints. With more than 5.2 million members in the U.S. and 5.6 million internationally, it is one of the fastest growing religions in the world.

The sheer growth the church worldwide has overtaxed Temple Square's facilities particularly the historic Tabernacle and other smaller assembly places. In 1996, its leaders undertook the construction of a facility that could accommodate the religion's bi-annual general conferences, attended by over thirty thousand people for each session. The structure would also need to host theatrical pageants and concerts. It was to be "a magnificent, beautiful and utilitarian place for the people of this church and for the people of the community... a distinguished building... in which there will be a greater refinement of the spirit felt."

The site the Church selected for this massive project was one of Brigham Young's ten acre city blocks, sloping upward sixty five feet from the southwest to the northeast toward the toe of Capitol Hill and the mountains beyond. Perhaps even more significant was the location of the facility directly on axis with Temple Square and across the street from the Tabernacle and Temple itself.

The requirements-seating for twentyone thousand people; space for lobbies and support areas; full facilities for
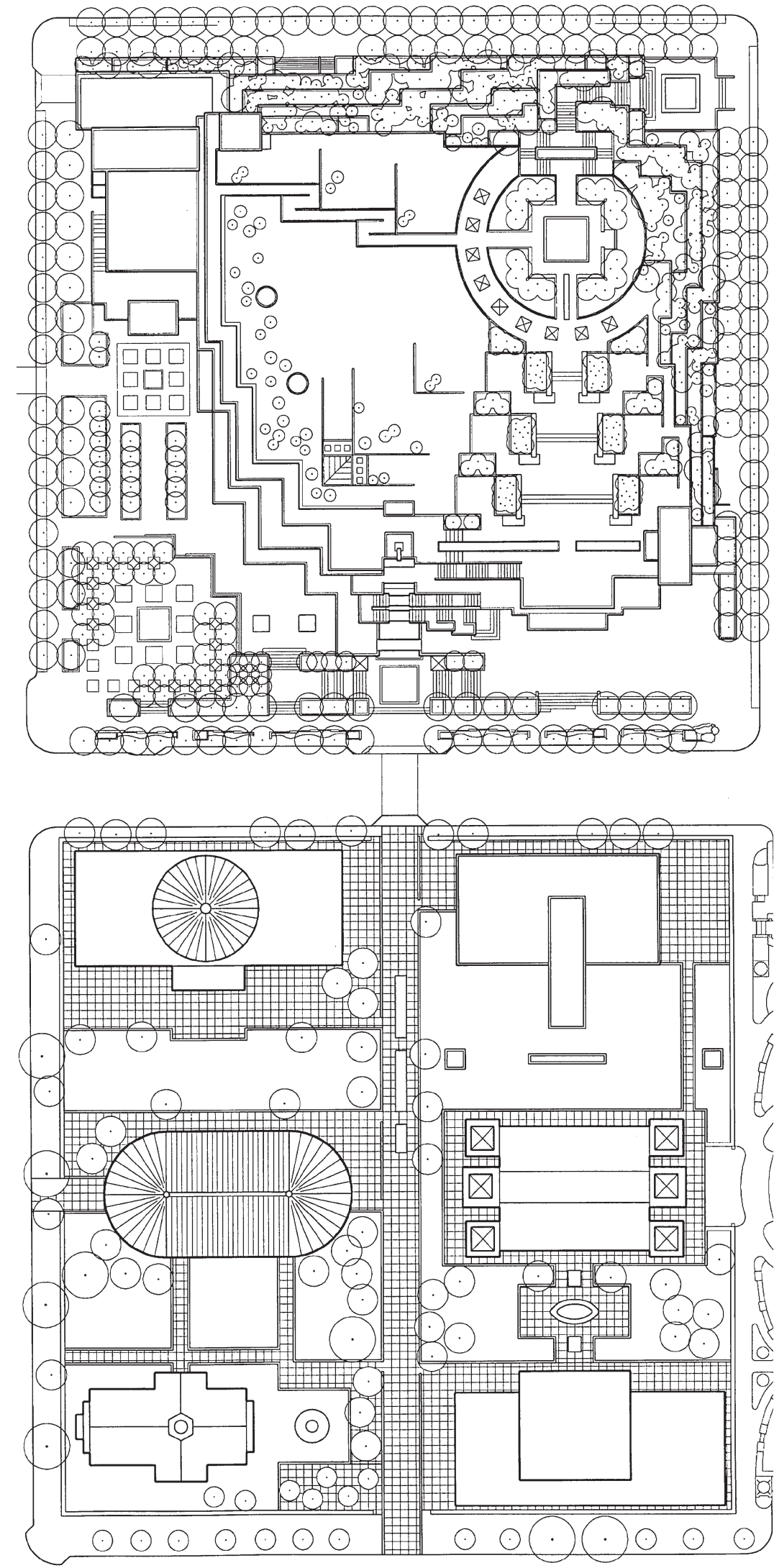

Conference Ceter and Temple Square. 
theatrical and audio-visual productions; and below-grade parking for 1,400 vehicles - ultimately would make this 1.1-million-square foot-auditorium one of the world's largest religious or assembly buildings.

The design team selected for this undertaking was led by architects Zimmer Gunsul Frasca; with landscape architects, Olin Partnership; structural engineers, KPFF, and theatre consultants, Auerbach+Associates.

Among the concerns of this collaborative team in approaching the design for a facility this large were the ability to create a building that was deferential to the Temple without overpowering it the preservation of strong visual axes; and the integration of the building into the fabric of Temple Square, the adjacent business and governmental districts, nearby residences, and to the greater valley and mountain landscape beyond. It was apparent to the design team that a building this large would also have an extremely large roof. A building with a seven- or eight-acre roof would be too big. It would be out of scale in itself and also would dwarf the Temple and surrounding buildings.

By understanding and acknowledging the relationship of the building to both the city and the greater landscape the strategy that emerged and was adopted by the design team was to submerge the structure into the landscape and become landscape itself.

While clearly a building, connected to the fabric of the city and to Temple Square, it would also become as much about the landscape as possible. This would be accomplished by incorporating the elements of water, stone, trees, and meadows, but not limiting or confining those key elements to the roof. They would also be integrated into the building itself, using great cascading fountains, planters, and monumental stairs. These landscape elements would remain referential to the larger landscape of Utah, particularly the Four Corners region where great mesas appear as long horizontal bandings of stone, lush vegetation in the valleys are eroded by ancient and modern waters, and the indigenous
Anasazi cut great stairways and built entire villages within the rock masses.

By taking advantage of the sixty-five foot difference in the elevation of the site, and submerging a large portion of the building below street level, it is possible to integrate the roof, balcony, terrace, and orchestra levels of the auditorium with an extensive system of exterior stairs, gardens, fountains, and a rooftop meadow. As approached from the lowest, southwestern corner, the building remains very much connected to the city, but as it moves uphill, toward the Capitol and the mountains, it becomes more referential to the greater, natural landscape of Utah.

The more public sides of the building - the south and the east-are at the lower and mid elevations of the site. These can be entered at both the orchestra and balcony levels. The highest elevations of the site, at the northeast corner, are integrated with the back-of-house functions for the auditorium. Here, the theatrical support systems of flyways, catwalks and rigging, which require the greatest heights, are cut into the slope. The east and north house walls and the curved rear house walls stand more than one hundred feet high. Along with four large mechanical shafts, these walls support the cantilevered balcony and the massive roof structure. Exterior retaining walls incorporate giant stepped planters filled with native vegetation that envelope the entire northern and eastern sides of the building.

To provide a column-free space for the entire auditorium, a radial long-span truss system with a transfer truss over the stage was employed. These trusses, spanning up to 290 feet, support the differing loads of the sloping rooftop gardens.

This extraordinary integration of program and structural system support the major landscape components of the building, all of which are created over or within artificial conditions.

Part of the purpose of integrating the landscape with the building was to 


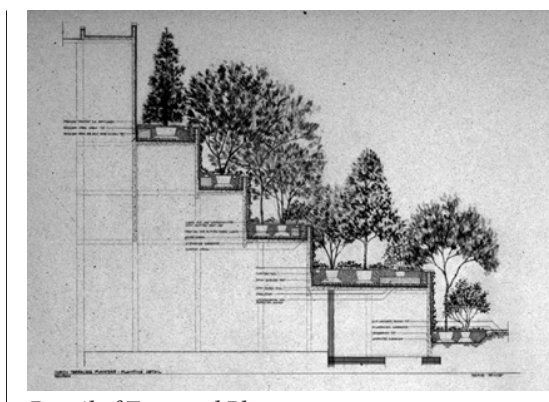

Detail of Terraced Planters.

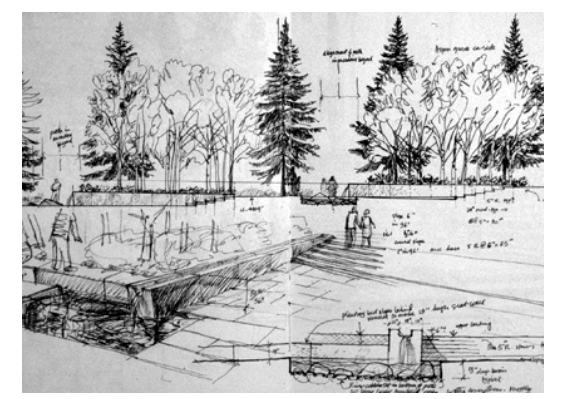

Concept Sketch.

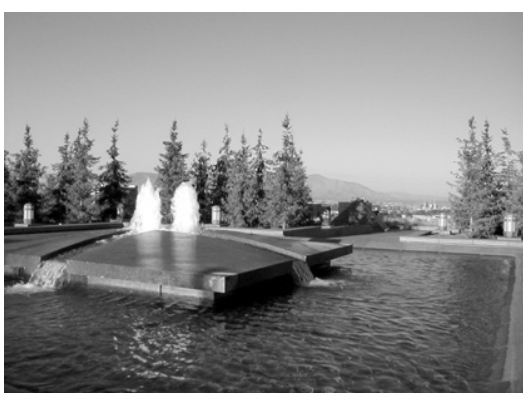

Source Pool.

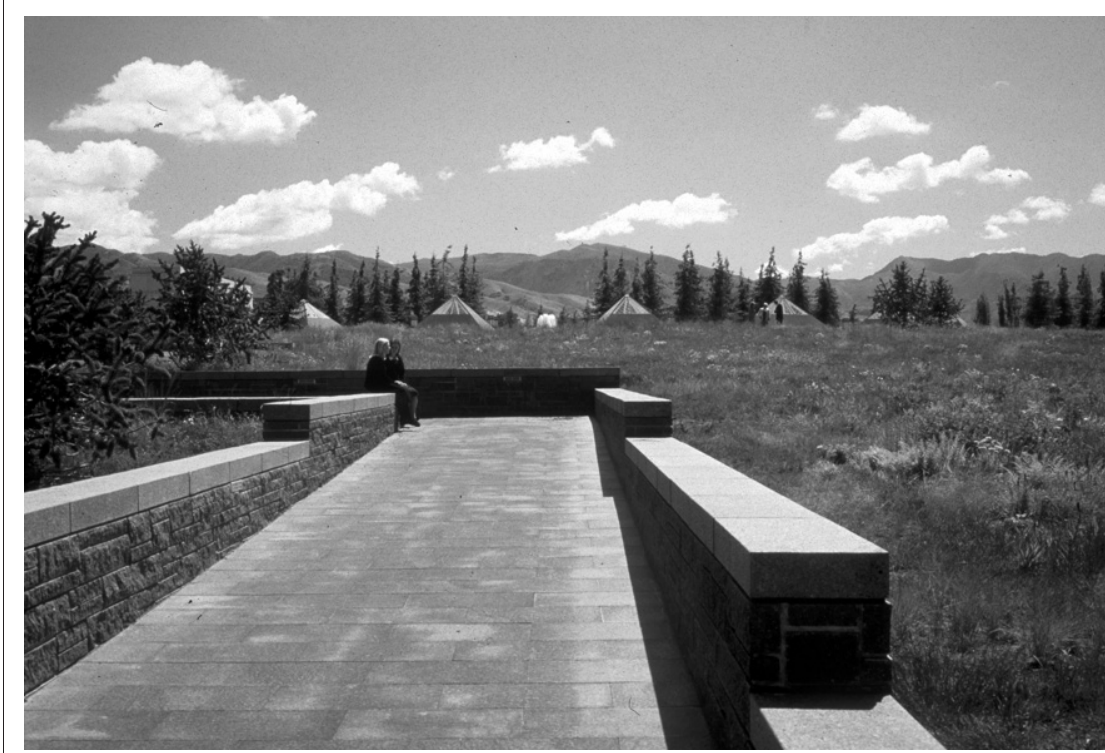

View to Source Pool Garden Across Rooftop Meadow. be sure that both would be seen as a whole, but one with many smaller, understandable and interrelated parts. It is not unlike experiencing a greater landscape at once as vast and complete, but with intimate, finely-textured, and complex spaces, each viewed from many perspectives.

Also fundamental to the design was balancing the immense size of the indoor and outdoor spaces to the experience of an individual user. So, just as the needs of a single viewer had to be met in the twenty-one thousand-seat auditorium (including unobstructed views and visual and audio intimacy), each of the major outdoor spaces needed to be large enough to welcome thousands of visitors on a conference day without impeding circulation, but with enough form and character to prevent the spaces from feeling empty on ordinary days. While the spaces must accommodate huge crowds, they still must offer adequate places for visitors to sit, and intimate areas for rest and reflection.

The resulting landscape consists of four major components: the Terraced Planters, the Fountain Plazas, a Central Garden and Source Pool, and a Meadow.

Enveloping the northern and eastern, granite-clad sides of the building, long, horizontal, terraced planters step from street level to the roof. They also enfold the grand stairway that leads to the rooftop garden from the northeastern corner. Analogous to the vegetated slopes of the nearby mountains, these

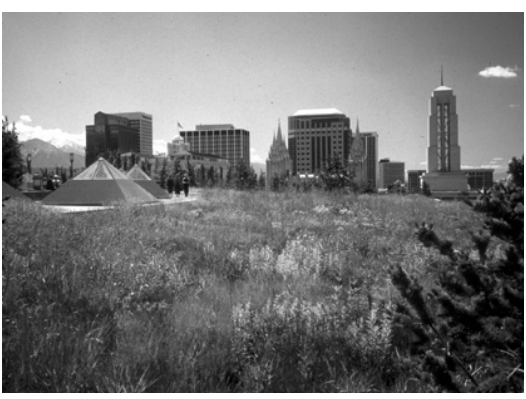

Rooftop Meadow.

terraces are filled with native varieties of coniferous and deciduous trees, understory trees, and ground covers. The bright spring and summer greens of the oaks, maples and mountain ash change to brilliant reds, yellows, and oranges in the fall, always contrasting with the dark banding of the conifers. From both a distance and from the adjacent sloping sidewalks, visitors see a building that appears to be alive with mountain vegetation.

The western and southern sides of the Conference Center are more programmatically and publicly active. Accordingly, the fountains, stairs, paving and plantings on these main-entrance sides, more architectural in form, are responsive to a visitor and to the axial relationship to Temple Square.

The lowest corner of the site is to the southwest. Here, where the city meets the building, lies the major pedestrian entrance to the Conference Center. It is where visitors are welcomed by a large, energetic fountain surrounded by a bosque of Golden Rain Trees, an initial greeting that offers places of respite containing shade, seating and-most notably-the first reference to water, whose source initially seems unknown.

The flow of water and of people continues to the main entrances of the building. The axis of Temple Square is emphasized on the main façade with a wall fountain whose water cascades down the entire face of the building. Using a system of elegant stairs and 
terraces one may actually climb the face of the building along, over and next to the water, up to the base of the rooftop garden.

There, the thread of water continues horizontally, placidly flowing through an elegant linear basin, broken only on the axis to the Temple and the Centra Garden. The views from the interior and exterior are led eastward back to the top of the water wall. At this level, the first, elevated, exterior views to the Temple and Temple Square become apparent, as do the thread of water and the promise of an enormous garden and landscape beyond.

Along the Temple's axis, a series of immense rectangular planters, monumentally wide stairs, and long runnels and basins of water step up the sloping roof to the source pool, meadow, and ultimately to the broadest view to the landscape beyond. The central garden's planters are splayed to emphasize the views in both directions and are oriented both parallel and perpendicular to the central axis. Such ninety-degree orientation contrasts the great groves of aspen planted parallel, with the dark stands of conifers stepping behind them. Additionally, smaller, more intimately scaled garden spaces are formed along the exterior edges of the planters, ideal for small groups or individuals.

At the very top of the central garden lies the Source Pool. Here, on axis with the Temple and enclosed by a serene, comforting ring of conifers, lies the source of the runnels and fountains for the entire garden and building. At this point, although the actual source remains obscured, the water begins its flow over a simple, elevated tableau formed by four monolithic offset granite quadrants set in a larger basin. From here, a visitor experiences multiple sources of serenity: one from the flow of water and the sense of enclosure, a second
Temple, and a third from the glimpse of the meadow to the east.

If the architectural form of the central garden, with its source pool, runnels, stairs and planters, provides a sense of appropriate grandeur and deference to the Temple, the meadow offers a balancing sense of the subtle and sublime. It completes the landscape metaphor of the Alpine meadow above the richly-vegetated mountain canyons eroded by the flowing waters, as found in the nearby Wasatch Mountains.

The view across the uninterrupted meadow, sloping gently with the roof of the auditorium below, yields to the city and mountains. A rich mosaic of native plants and grasses, punctuated by only a few clumps of Pinyon Pines, provides a sense of human scale both in contrast and harmony with the greater landscape beyond.

The meadow plants and grasses were selected from a native palette but included species that could provide the richest range of colors and textures when the most people experience it-during spring and fall conferences. Dominant within the matrix of grasses are those that are brighter and greener in early April and hold their color into October. The flowering plants also peak during those months.

Showing a tremendous commitment to the natural and spiritual strength of the meadow, the church undertook the unprecedented and almost unthinkable effort of hand planting every grass and perennial on the nearly three-acre rooftop meadow. The effort was a collaborative one of the contractors, the Olin Partnership, the church landscape architect, and volunteers. We selected the plants and grasses, determined their numbers and had them grown to detailed specifications. The flowering plants were supplied in one-gallon plastic pots. The grass was produced by seeding it into small plastic tubes or "plugs" that could be

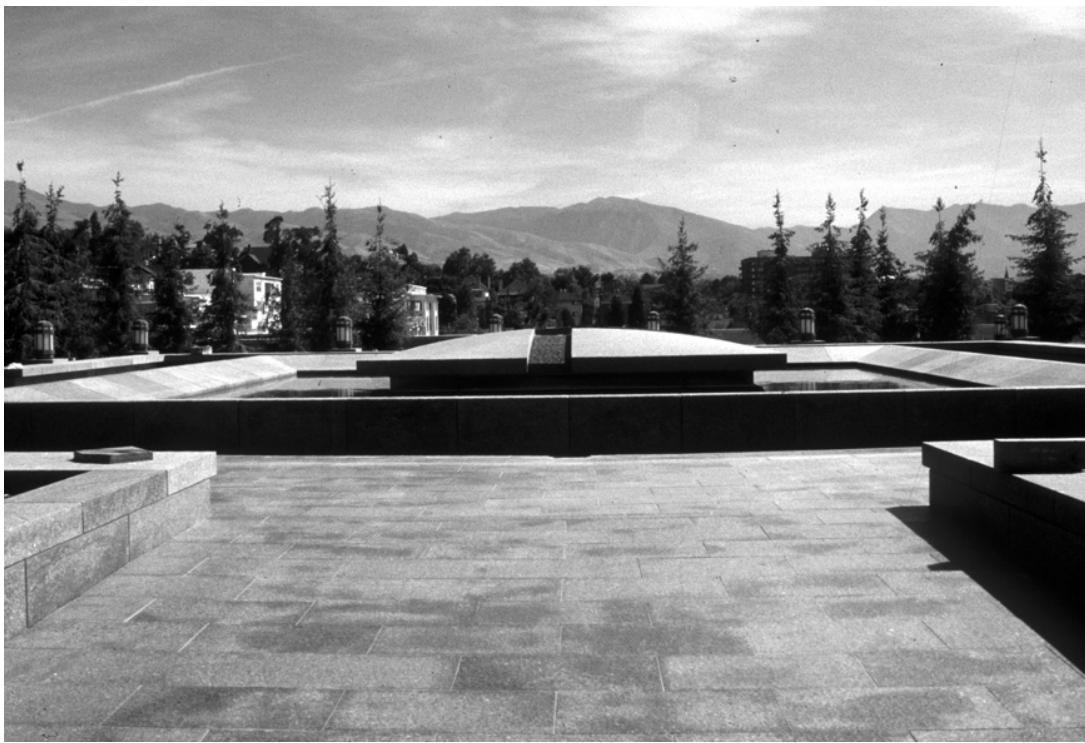

Source Pool.

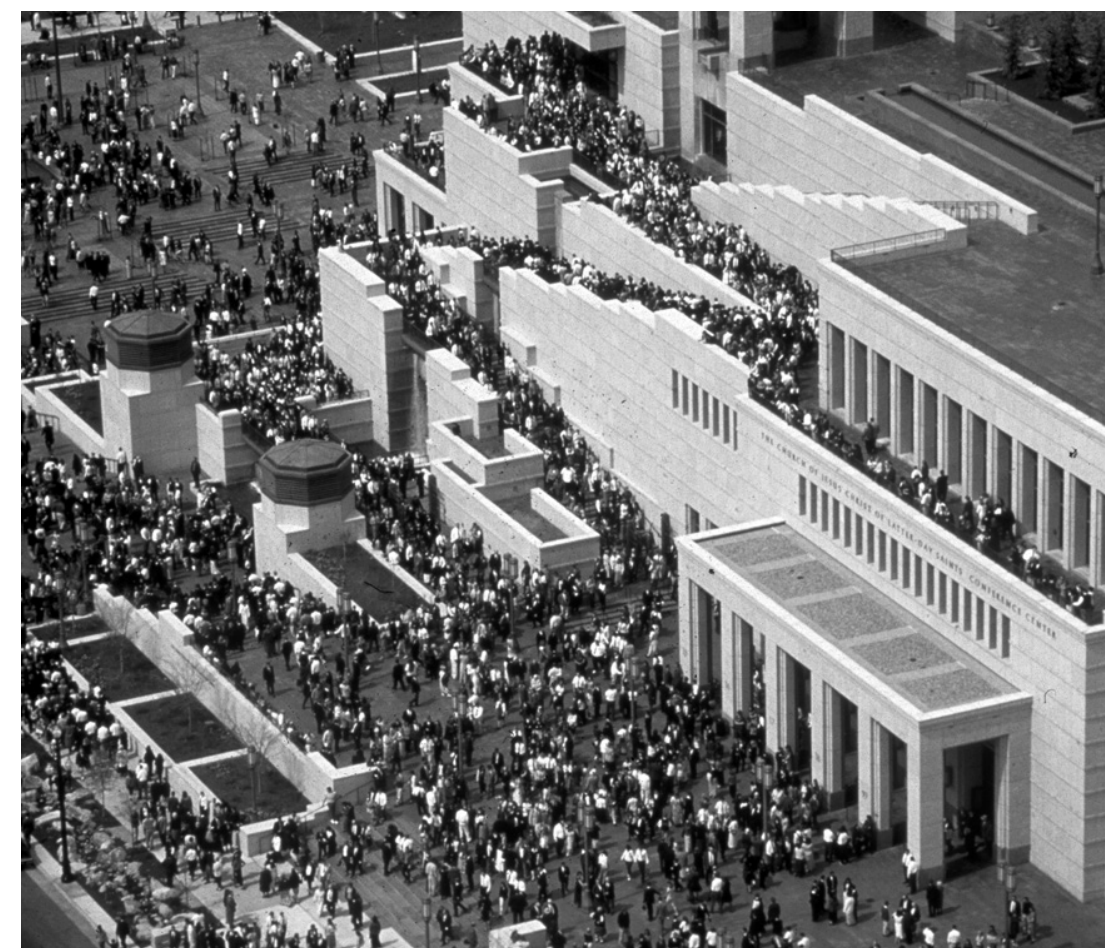

Main Entrances on Conference Day. 


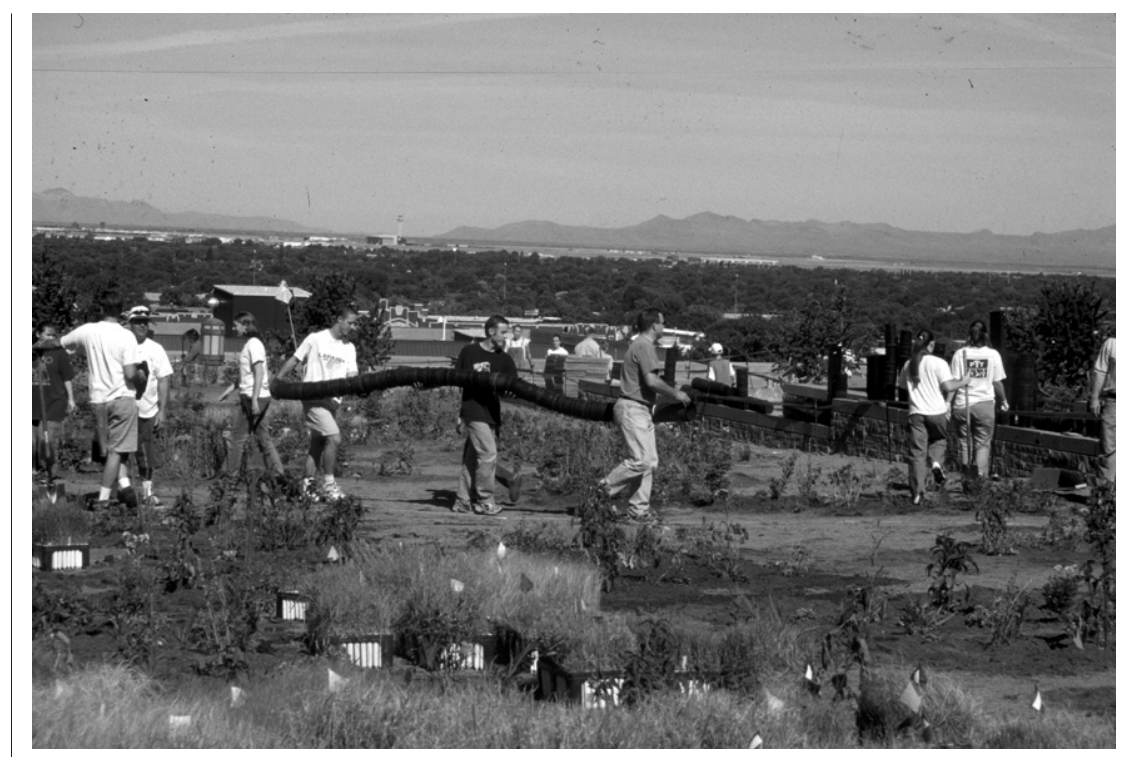

Volunteers Planting Rooftop Meadow.

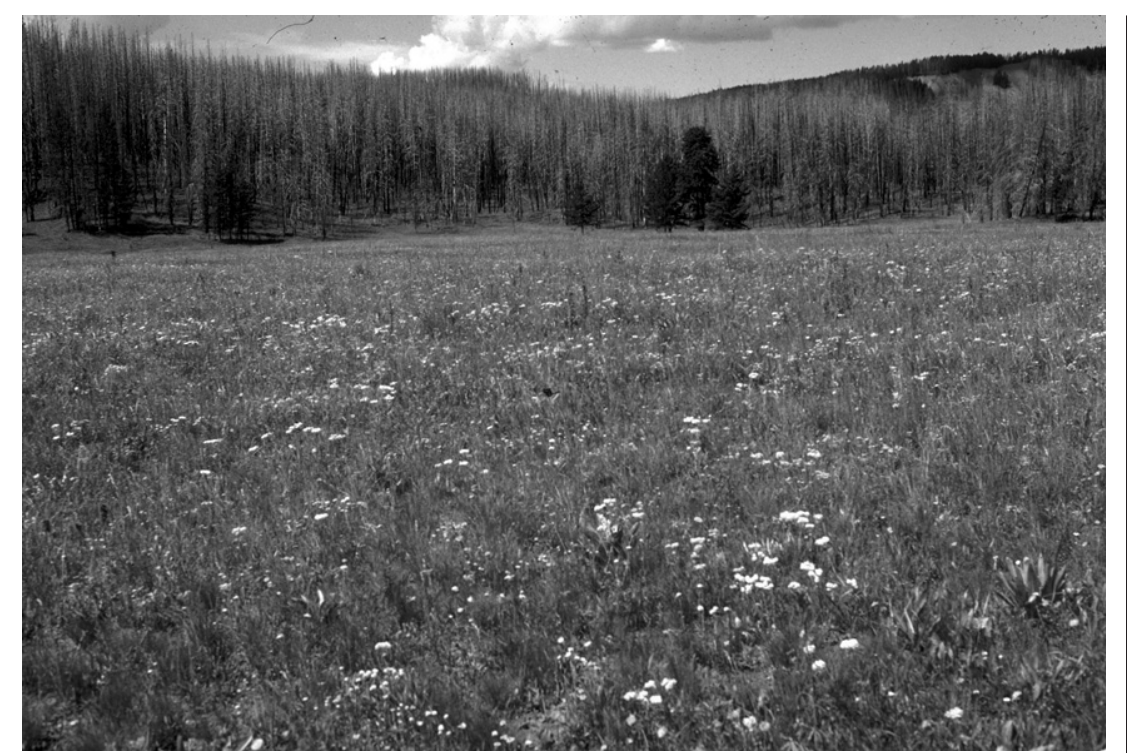

Meadow. transplanted. More than one thousand volunteers hand-carried flats of plants and grasses from the street to the rooftop, bucket-brigade style. Landscape architects and the Church garden staff determined where in the meadow each plant would go, and the volunteers then hand planted each perennial and plug. The gigantic effort produced in two weekends what would in nature have taken a generation or two.

Still, what might seem a remarkable acceleration of nature becomes more understandable when one considers the entire landscape-paving, stairs, fountains, and plantings-is not natural at all, being constructed over a massive slab of concrete and steel. The paradox, of course, is that the natural-appearing landscape is maintained by a wholly artificial support system. Below the stone, fountains, gardens, meadows, and terraced planters lies a complex system of fountain and irrigation lines, polystyrene blocks, plastic drainage matting, elastormeric waterproofing, and inert, lightweight "soils."

Above this engineered labyrinth, we used natural materials in ways that responded both to the form of the building and to the landscape beyond. That ideal was fundamental to integrating structure and landscape. Water, stone, and plants are used in architectural shapes and spaces that refer to natural places; acknowledging that nature cannot be recreated, but can be evoked. Furthermore, the spaces and shapes were not intended to be overtly religiously symbolic, or overly interpretive, allowing any interpretation, whether literal, metaphorical, poetic or spiritual, to come from the user.
Just as the Conference Center itself, an extraordinarily elegant and sophisticated auditorium, ultimately must support the religious and spiritual needs of its users, so must the landscape. The integration of the form and function of the Conference Center with the greater landscape was intentional on the part of the designers. Yet, its ultimate success should be measured on a daily basis by the perception and interpretation by church members, visitors and citizens of Salt Lake. Standing atop a meadow, situated above a twenty-one thousand-seat auditorium and looking out over the city and larger landscape beyond, does the user need to consider the larger web of urban infrastructure and ambiguous complexities-or is it enough to take in the view and think, simply, "This is the place."

\section{Notes}

1. President Gordon Hinckley, Remarks at Groundbreaking (compiled in: The Conference Center, The Story of Its Construction).

\section{Project Credits}

Client: The Church of Jesus Christ of Latterday Saints

Architects: Zimmer Gunsul Frasca, Robert Frasca, Principal

Landscape Architects: Olin Partnership, Laurie Olin, Principal; Susan Weiler,Principal, Project Team: David Rubin, Michelle McCormick, David Elliott, Leslie Hey, Les Bishop

Engineers: KPFF Consulting Engineers (structural); CHP \& Associates (mechanical and electrical); EWP (civil); CMS Collaborative (fountain)

Theatre Consultants: Auerbach+Associates Acoustics: Jaffe Holden

Associate Architects: Gillies Stransky Brems Smith 